\title{
Curriculum Evaluation on Pedagogical Courses in Industry 4.0 era: Describing Alumni Views
}

\author{
D P Ratri ${ }^{1}$, D N Dewi ${ }^{2}$, Y Hapsari $^{3}$ \\ ${ }^{1,2,3}$ Universitas Brawijaya \\ \{1devinta@ub.ac.id, ${ }^{2}$ diannovita@ub.ac.id, ${ }^{3 h}$ hapsari.yulia@ub.ac.id\}
}

\begin{abstract}
This study is aimed at describing alumni feedback who work as teachers on the pedagogical courses offered at ELEP in their job as a teacher and how sufficient the pedagogical courses offered at ELEP for the alumni to do their job as a teacher. This study employs descriptive qualitative as it attempts at describing ELEP alumni current opinion about how well pedagogical content on ELEP curriculum helps them as a teacher. Interview had done to collect alumni views toward the issue. The result shows that that the content of some pedagogical courses such as Pengantar Pendidikan and Etika Profesi need to be improved to add more practical knowledge than theoretical knowledge. Students need more exposure on the real view of what happen in the real teaching and learning process in high school. All in all, all pedagogical courses are needed and most of the pedagogical courses are sufficient but there should be improvement on teaching implementation for betterment.
\end{abstract}

Keywords: Alumni Feedback, Pedagogical Competence, Curriculum Evaluation

\section{INTRODUCTION}

English Language Education Program (ELEP) aims at producing English teachers who master the concept, theory, and the application of teaching pedagogy. A teacher must be equipped with four competences covering (1) pedagogical competence, (2) personal competence, (3) social competence, and (4) professional competence[1]. Therefore, those competences must be covered in the objectives of ELEP to answer the qualification proposed by the government and to accommodate the needs of society in education field or teaching English as a foreign language.

Regarding the need of society in the millennial era, education institutions demand high standard qualifications for the English teachers. To fulfill this, curriculum for the undergraduate students in ELEP designed to provide solid pedagogical knowledge and practical knowledge for individuals who are ready to teach and apply the knowledge in the workplace especially in teaching millenial students who are familiar with technology and gadget. Hence, to keep the curriculum up to date, the evaluation on curriculum should be done continuously. The quality evaluation is done to ensure that the program has already fulfilled the quality assured which cover the nine evaluation areas for quality assurance namely, vision, mission, educational goals and learning outcomes; curriculum design and delivery; assessment of students; students selection and support services; academic staff; educational resources; programme monitoring and review; leadership, governance and administration and continuous 
quality improvement[2]. In line with that statement, as education institution, ELEP continuously conduct the evaluation of the curriculum to accommodate the society's need and the standard of teachers based on the Decree of National Education Ministry no. 16 year 2007.

The program must control the quality assurance of the curriculum. To sustain the quality of curriculum, curriculum evaluation is worth to conduct. Basically, a major concept of curriculum evaluation occurs after the courses have been taught four times[3]. In another words, the curriculum needs to be revised after five years applied. This study focuses on pedagogical curriculum evaluation that is a prominent component in teaching and learning. In this evaluation process, it takes into account stakeholders which refer to the alumni of ELEP who are the key participants of pedagogical curriculum evaluation. In this case, the alumni are as the providing evidence of their outputs in pedagogical competence and the relevance of what they have learned to their needs [4]. Hence, this study attempts to evaluate the pedagogical curriculum offered by ELEP from alumni feedback in their job as a teacher. Taking pedagogical competence as the focus to be examined in this study is based on a consideration that pedagogical knowledge and skills are pivotal aspects of being a teacher. Teachers need to possess a body of knowledge involving, among which, knowledge of subject matter and pedagogy, including pedagogical content knowledge [5]. Thus, teachers have to possess a great deal of pedagogy as they are involved with pedagogy every working day of their life [6].

As a program study which produces English teachers, English Language Education Program designed a curriculum that equips students with pedagogical competence for teaching English. Since curriculum is a dynamic object that is developed based on the needs of society and the individual university [3], it must be evaluated periodically to keep it up to date. To prevent drift and maintain quality, continuous review on curriculum is obligatory. For curricula to be relevant to the needs of society, faculty must be committed to continuous quality improvement, which involves curriculum evaluation, curriculum revision, and reevaluation after implementation of changes [3]. There are a variety of methods of curriculum review and evaluation which involves both formative and summative evaluation. Formative evaluation assesses the program for the period of development and implementation to find where changes are required and to ensure quality. While summative evaluation controls if the program outcomes were met [3]. This study focuses on the summative evaluation which aims at finding out about how well English Language Education Program equips the students with pedagogical competence. The 5 year process curriculum evaluation is presented in picture below.

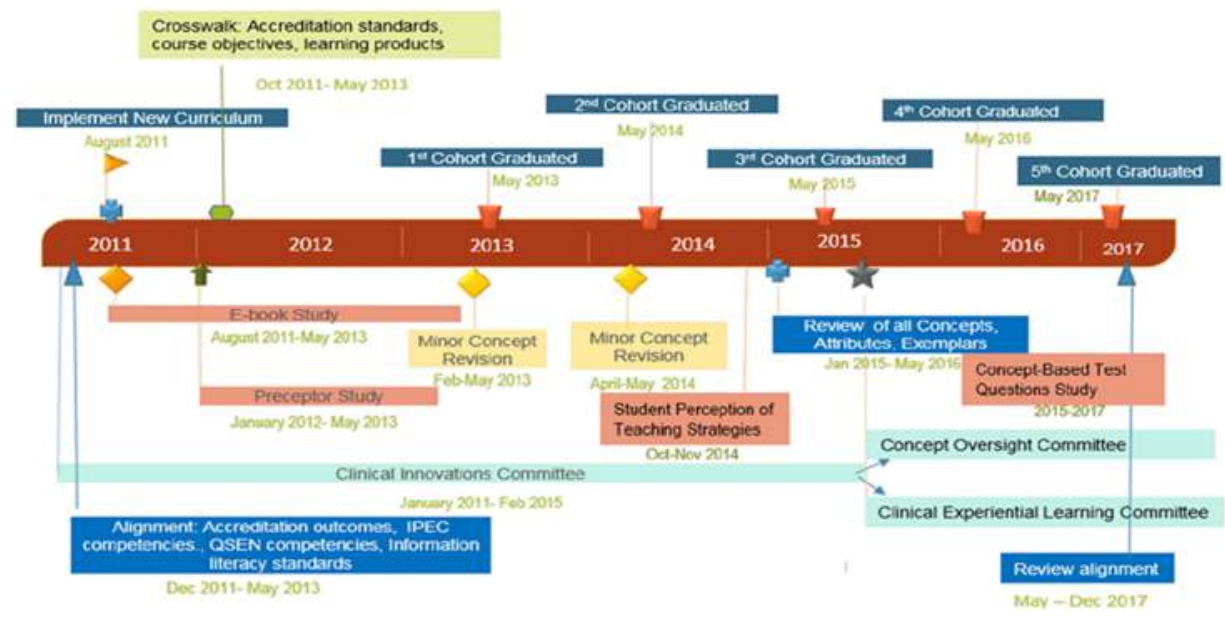


Figure 1. 5 year process curriculum evaluation [3]

In this research, curriculum evaluation is done in the stage of alumni survey to obtain feedback towards the pedagogical courses in term of to what extend the alumni need them in their job as teachers and how sufficient the pedagogical courses were offered at ELEP for the alumni to do their job as a teacher. The input of alumni is vital to the development and improvement of the program [7]. More precisely, it is very useful in constructing programs in curriculum. In this research, alumni were asked about the benefits of pedagogical courses for their job as teachers to evaluate the materials given in pedagogical courses. This as consideration for lecturers of English Language Education Program review, revise, and develop pedagogical courses for improvement.

Some studies done in the similar area of curriculum evaluation. As it was conducted on a Study of Alumni Feedback on Outcome Based Education in the Faculty of Engineering \& Built Environment, Universiti Kebangsaan Malaysia [8]. Survey results show high overall values of alumni perception of program objectives and program educational outcomes. Another also did a similar study on A Study of English Language Curriculum Implementation in 6th, 7th and 8th Grades of Public Primary Schools through Teachers' and Students' Perceptions [4]. The results revealed that the implementation process of the English language curriculum showed that majority of the curriculum goals were attained at a moderate level and there were some problems with the selection and ordering of curriculum content. Teachers' perceptions of curriculum goals and content differed in relation to school location, age, teaching experience and educational background. Students' perceptions of the curriculum varied in relation to their grade levels, gender, parents' educational and English level and previous English grade. Similar study concerning about curriculum was done that is Impact of Alumni Feedback on the Curriculum [7]. To be specific, it discusses the use of an alumni survey as feedback for the development and improvement of a mechanical engineering program curriculum. The alumni feedback gave valuable input to the improvement of the curriculum. Knowing the importance of alumni feedback for the improvement of study program curriculum, it is essential to carry out curriculum evaluation on the view of alumni who worked as teacher whether the pedagogical curriculum needed and suffiently equipped them in the workplace.

\section{RESEARCH METHOD}

This study employs descriptive qualitative to cope the alumni's perception. As this study aims at describing ELEP alumni current opinion about how well pedagogical content on ELEP curriculum helps them as a teacher, a descriptive qualitative design using an in-depth interview to collect qualitative data was conducted. The process of research in qualitative method involves emerging questions and procedures, the typically data were collected in the participant's setting, and the building of the data analysis was inductively come from specific to general themes [9]. In other words, the interpretations of the data were reported descriptively. The qualitative data were obtained from alumni who have already worked as teachers from different area of educational field. The subjects were chosen based on their length experiences of teaching. The final written report had a flexible structure. Here, the researcher used form words to describe the result of the study. 


\section{RESULT AND DISCUSSION}

\subsection{Results of the Study}

Some questions were developed as a semi-structured interview guideline to get qualitative data. Some alumni were carefully selected as informants to reveal intended information. One alumni representing majority response was chosen randomly while three other alumni were appointed as they have the longest experience of teaching from the majority ones. Then, the interview results were transcribed and analysed further to get complete picture of the alumni's feedback on the pedagogical courses offered at ELEP.

The interview results answer the curiosity by revealing reasons behind the alumni's response. Among the 13 pedagogical courses listed in the questionnaire, some courses such as Pengantar Pendidikan (Introduction to Education), Psikologi Pendidikan/Pembelajaran (Psychology of Education/Learning), Program Pengalaman Lapangan (Pre-service Teacher Internship Program), Etika profesi (Ethique), Teaching English as a Foreign Language, Curriculum of English Instruction, Instructional/Teaching Media, Language Assessment, Classroom Management, Language Teaching Methodology, English for Young Learners, Micro Teaching, and Instructional Material Development are considered to be good and simple. Thus, it facilitates the alumni to understand the material well.

Some of the pedagogical courses such as Instructional Material Development, Curriculum of English Instruction, Classroom Management and Language Teaching Methodology are considered to really help the alumni in not only preparing teaching material, planning teaching-learning activities, and manage the class. However, one of the alumni argued that Pengantar Pendidikan and Etika Profesi still remain as theoretical knowledge as during the teaching of the courses, empirical phenomena related to the theory were not adequately explored yet.

The extend of which the participants need the pedagogical course are based on specific job description of each alumni as an English teacher. A participant argued that among those courses, $60 \%-70 \%$ are needed in teaching junior and senior high school students, while some other believed that all of them are needed in their job as a teacher in language school whose students' English proficiency varies. For a participant who has experience in teaching English for young learner, $40 \%$ of the pedagogical courses are needed as some courses such as Language Assessment and Teaching English as a Foreign Language are not applicable in Elementary school context.

Though all the pedagogical courses are needed, they do not share the same degree of sufficiency in equipping the alumni with knowledge and skills needed to do their job as an English teacher. All of the alumni being interviewed stated that Instructional Material Development, Language Teaching Methodology, Teaching Media, Psychology of Education/Learning, Teaching English as a Foreign Language, English for Young Learners, and Micro Teaching are pedagogical courses that successfully equipped them well with knowledge and skill that are really helpful in doing their job as an English teacher. Psychology of Education/Learning, for example, equips the alumni with knowledge of how to deal with millennial students to develop their sense of responsibility and awareness. Moreover, teaching millenials is obliged to have more updated strategy related to technology since it increases their motivation in involving in teaching and learning process. Next, Micro Teaching, as another example, gets some feedback that it should be an individual (not a pair) in doing task as teacher, and that it needs to involve more than peer playing role as students. Among the pedagogical courses that are needed, yet in need of some improvement are recommended. 
All in all, from the results, it is concluded that most of pedagogical courses offered in ELEP is needed, but few of them such as Pengantar Pendidikan and Etika Profesi need to be taught in more practical knowledge so that the students can get clear picture of their implementation in real teaching process. For the sufficiency of the materials given pedagogical courses, most of them are sufficient in equipping alumni as teachers. Nevertheless, improvement on the teaching technique and scenario in class is highly required since the theoretical knowledge is quite boredom to be given in the classroom, they argue that it is something that they can earn by themselves by reading books and articles. The most valuable thing expected from learning pedagogical courses at college is the exposure of how the theory implemented in the real class or in other words students demands more practical knowledge especially in handling millenial students. Therefore, revisiting the teaching technique and scenario for pedagogical courses in ELEP is vital for curriculum improvement.

\subsection{Discussion}

Based on the results of questionnaire and interview, most of the respondents agreed that most of pedagogical contents equipped them knowledge and skill as English teachers. A few alumni considered to response differently since the needs of the students are different. The pedagogical content is the compulsory course which must be taken by ELEP students to accomplish pedagogical knowledge. A teacher must be equipped by knowledge and skill and one of the knowledge is pedagogical knowledge [4]. Richards states core competence of teacher knowledge consists of (1) practical knowledge, (2) content knowledge, (3) contextual knowledge, (4) pedagogical knowledge, (5) personal knowledge, and (6) reflective knowledge. Pedagogical knowledge itself can be defined as an ability to plan and construct teaching content by taking into account the learning objectives. This ability must be gained by teachers as it is stated on the Decree of National Education Ministry no. 16 year 2007 as the standard of teachers.

This study is firstly conducted to evaluate ELEP's curriculum especially on pedagogical content. As the purposes of this study, the results answer the issues to investigate the need of alumni on the pedagogical courses offered at ELEP in their job as a teacher and how sufficient of the pedagogical courses offered at ELEP for the alumni to do their job as a teacher are. Most of alumni really need and they are quite sufficient on pedagogical courses such as Language Teaching Methodology, Curriculum of English Instruction, Classroom Management, and Instructional Material Development since they were involved directly. In another word, they did the plan and applied it at school. This learning experience facilitated them well when they do the job as a teacher. Thus, it can be concluded that the alumni still perceive these pedagogical contents are important and thus may be kept in their current form.

Regarding curriculum evaluation, this study accommodates ELEP to examine the effects of a program at significant end points of an educational cycle [4]. This process can be defined as accountability-oriented evaluation. This evaluation is aimed at measuring in what extent the quality or the benefit of the programs facilitated stakeholders. The result can be used to decide to still perceive the pedagogical courses or to modify even to change the courses. To be specific, the results show modification is suggested on the method of teaching some pedagogical courses. As mentioned [3] curriculum evaluation can be whole or part of the curriculum, and in this study evaluation is segmented in the pedagogical courses. Therefore, based on alumni views on betterment of the curriculum, four themes address curriculum revision: incorporating safety and quality, redesigning conceptual frameworks, incorporating strategies to address content-laden curricula, and using alternative teaching pedagogies [10]. 
In this study, it is figured out that ELEP need to revise alternative teaching pedagogy in some courses. Alumni proposes that it is more beneficial in equipping their job as teacher if pedagogical courses given in practical not only theoretical. An idea of teaching method and strategy used in pedagogical courses is ICT based since teachers nowadays assist millennial generation who engage with gadget and technology. Educational systems all over world are now highly related with the use of information and communication technologies (ICT) [11], this aims at equipping students the knowledge and skills needed to face digital era nowadays. In short, teaching method which is more practical and involving ICT is highly recommended to be implemented in teaching pedagogical ELEP to equip teachers to be.

\section{CONCLUSIONS}

From the study done to ELEP alumni, it uncovered that all pedagogical courses are needed for alumni who work as teachers. Though, it revealed in in-depth interview that some of the pedagogical courses, such as Pengantar Pendidikan and Etika Profesi are still remain as theoretical knowledge as they did not explore empirical phenomena related to the theory. Nevertheless, it is suggested that the content of some pedagogical courses such as Language Teaching Methodology and Micro Teaching need to be improved to add more practical knowledge focusing on keeping up with millenial students. ELEP students need more exposure on the real view of what happened in the real teaching and learning process in high school. All in all, all pedagogical courses are needed and sufficient but there should be improvement on teaching implementation for betterment.

It is suggested to ELEP to revisit its pedagogical courses especially on how they are delivered since the result shows that some pedagogical courses delivered in the class still focus on theoretical, while as teachers, they need more practical knowledge. Furthermore, for further researchers are suggested to investigate deeper on what teaching technique/scenario which matches to teaching pedagogical courses and give more horizon about practical knowledge which is valuable for ELEP students in equipping them for their future job.

\section{REFERENCES}

[1] B. Sudibyo, "MENTERI PENDIDIKAN NASIONAL," p. 31.

[2] N. Khatimin, D. A. Wahab, and A. Mohamed, "Postgraduate Alumni Survey of the Faculty of Engineering and Built Environment," Procedia - Soc. Behav. Sci., vol. 18, pp. 110-117, 2011.

[3] S. Kumm and D. M. Laverentz, "Concept-Based Curriculum Evaluation: 5-Year Process,” Teach. Learn. Nurs., vol. 12, no. 4, pp. 242-245, Oct. 2017.

[4] J. C. Richards, Curriculum Development in Language Teaching. United Kingdom: Cambridge University Press, 2001.

[5] N. Pantic and T. Wubbels, "Teacher Competencies as a Basis for Teacher EducationViews of Serbian Teachers and Teacher Educators." 2010.

[6] Mortimore, "Does educational research matter?," Br. Educ. Res. J., vol. 26, No. 1, pp. 524, Feb. 2000.

[7] N. Younis, "Impact Of Alumni Feedback On The Curriculum," p. 9, 2002.

[8] B. Md. Deros, A. Mohamed, N. Mohamed, and A. K. A. M. Ihsan, "A Study of Alumni Feedback on Outcome based Education in the Faculty of Engineering \& Built Environment, Universiti Kebangsaan Malaysia," Procedia - Soc. Behav. Sci., vol. 60, pp. 313-317, Oct. 2012. 
[9] J. W. Creswell, Research design: qualitative, quantitative, and mixed methods approaches. 2013.

[10] M. O. Forbes and M. T. Hickey, "Curriculum Reform in Baccalaureate Nursing Education: Review of the Literature," Int. J. Nurs. Educ. Scholarsh., vol. 6, no. 1, Jan. 2009.

[11] A. Jimoyiannis and V. Komis, "Examining teachers' beliefs about ICT in education: implications of a teacher preparation programme," Teach. Dev., vol. 11, no. 2, pp. 149173, Jul. 2007. 